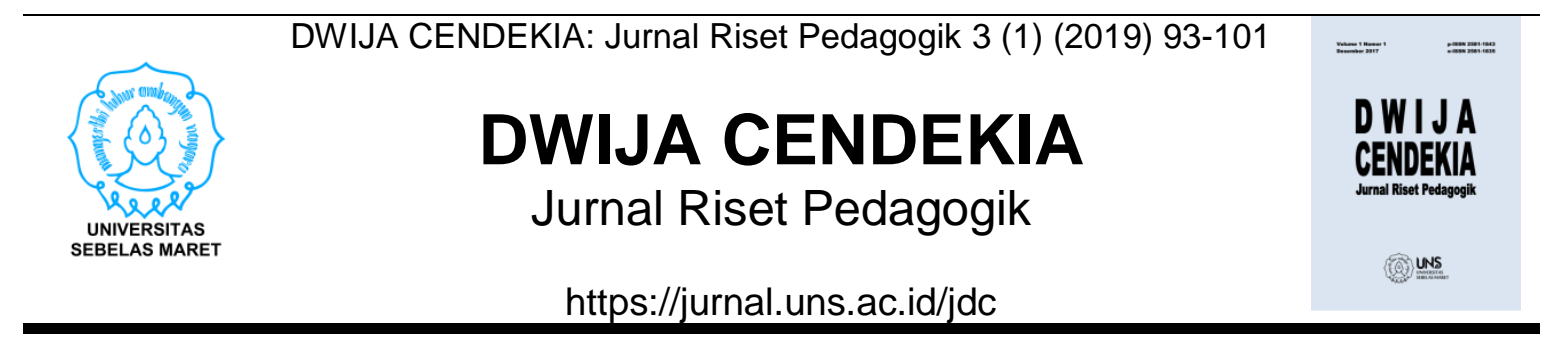

\title{
Ecobrick sebagai Sarana Pengembangan Diri Berbasis Ecopreneurship di Sekolah Dasar
}

\author{
Sani Aryanto, Markum, Vira Pratiwi, Cahyadi Husadha \\ Universitas Bhayangkara Jakarta Raya \\ sani.aryanto@dsn.ubharajaya.ac.id
}

\section{Sejarah Artikel}

diterima 20/08/2019

\begin{abstract}
EcoBrick is interpretation of the development of Ecopreneurship in elementary school. It is considered as a preventive and curative effort in anticipating the garbage problem Indonesia. The research aims to provide an overview of the development of EcoBrick program in elementary school as a means of internalization of ecopreneurship values in early stage. $A$ qualitative approach with a descriptive analysis method has been made to give the idea that the ecoprenuership concept is considered precisely taught in elementary school because it is technically easy to do. Every elementary school student is expected to actualize its ability to create, develop, and make ecobrick into goods that have value and for sale. Therefore, this concept is considered representative and innovative in making self-development program that can be used as means of internalization of ecopreneurship values in elementary school.

Keywords: ecobrick, ecopreneurship, elementary school
\end{abstract}

\section{Abstrak}

Ecobrick adalah bentuk interpretasi pengembangan konsep ecopreneurship di Sekolah Dasar (SD) dan dianggap sebagai upaya preventif dan kuratif dalam mengantisipasi permasalahan sampah yang terjadi di Indonesiai, sehingga tujuan penelitian ini adalah untuk memberikan gambaran pengembangan program ecobrick di SD sebagai sarana internalisasi nilai-nilai ecopreneurship sejak dini. Pendekatan kualitatif dengan metode analisis deskriptif yang telah dilakukan memberikan gambaran bahwa konsep ecoprenuership dipandang tepat diajarkan di SD dikarenakan secara teknis mudah dilakukan dan tidak terlalu rumit. Setiap siswa SD diharapkan mampu mengaktualisasikan kemampuannya dalam membuat, mengembangkan, dan mengkreasikan ecobrick menjadi barang-barang yang memiliki nilai guna dan jual. Oleh karena itu, konsep ini dipandang representatif dan inovatif dalam membuat program pengembangan diri yang dapat dijadikan sarana internalisasi nilai-nilai ecopreneurship di SD.

Kata Kunci: ecobrick, ecopreneurship, sekolah dasar 


\section{PENDAHULUAN}

Berdasarkan hasil Global Competitive Index, Indonesia berada diperingkat 45 dari 140 negara (Setiawan, 2018). Pencapaian itu tidak cukup baik apabila melihat demografi Bangsa Indonesia saat ini. Salah satu permasalahan serius yang menjadi perhatian dunia terhadap Indonesia adalah permasalahan sampah, khususnya sampah plastik. Sehingga tak heran Indonesia dinobatkan sebagai negara urutan kedua sebagai penyumbang sampah terbesar di dunia (Wahyuni, 2016).

Tidak dapat dipungkiri, permasalahan amoralitas penduduk Indonesia dalam memperlakukan sampah plastik yang menyebabkan kuantitas sampah semakin tak terbatas. Dalam lingkup nasional, (dengan asumsi jumlah penduduk 180 juta jiwa, laju produksi sampah setiap orang adalah dua liter perhari dengan komposisi 6,17\%) sehingga jumlah timbunan sampah di Indonesia setiap tahunnya dapat mencapai 1.599 .000 ton (Oktapianto, 2016).

Sampah memang dipandang sebagai sebuah benda yang tidak bernilai dan berharga, sehingga tak jarang diperlakukan dengan tidak sewajarnya oleh sebagian besar manusia. Ketidakwajaran ini yang membuat sebagian besar manusia terdorong untuk membuang sampah seenaknya tanpa memperdulikan dampak yang ditimbulkan terhadap kesehatan, sosial, ekonomi, dan budaya. Padahal kini Indonesia menjadi negara darurat sampah.

Menurut data Kementrian Lingkungan Hidup dan Kehutanan, bahwa Indonesia memproduksi sampah hingga 65 juta ton pada 2016 tahun lalu. Dan jumlah sekarang naik 1 juta ton dari tahun sebelumnya. Berdasarkan laporan Menteri Lingkungan Hidup dan Kehutanan Siti Nurbaya mengatakan sampah yang dihasilkan berdominan sampah organik yang mencapai sekitar 60 persen dan sampah plastik yang mencapai 15 persen dari total timbulan sampah, terutama di daerah perkotaan. Sesuai data tersebut menunjukan dalam 10 tahun terakhir banyaknya sampah plastik terus meningkat (Kurnia, 2019).

Kurangnya sarana Tempat Pembuangan Sampah (TPS) menjadi alasan sebagian besar masyarakat membuang sampah tidak pada tempatnya yang berimplikasi terhadap peningkatan volume sampah di kotakota besar. Padahal beberapa kota sudah mengupayakan upaya kuratif melalui perluasan area TPS, peningkatan regulasi, dan beberapa program berbasis lingkungan. Salah satu contoh kongkret upaya kuratif penanganan sampah dilakukan pemerintah kota bekasi dengan memperluas lahan TPA. Menurut Indopos (2019) "Kebutuhan lahan untuk pembuangan sampah di Tempat Pembuangan Akhir (TPA) Sumur Batu, Bantargebang, Kota Bekasi nyaris habis. Padahal, baru saja pemerintah daerah setempat menambah lahan seluas 3,5 hektare untuk lokasi pembuangan baru sampah untuk warganya". Artinya upaya kuratif saja tidak cukup dan diperlukan upaya preventif agar masalah ini tidak terjadi terus menerus. Apalagi Indonesia diyakini akan mengalami era keemasaan di tahun 2045 dengan potensi generasi muda lebih banyak dari pada generasi 
tua dan berada pada titik yang sangat produktif, cerdas, dan kompetitif. Oleh karena itu, upaya preventif yang dapat dilakukan adalah penginternalisasian nilai-nilai ecopreneurship melalui pengembangan ecobrick di Sekolah Dasar (SD).

Sekolah Dasar (SD) dianggap sebagai jenjang yang paling tepat dalam upaya internalisasi nilai-nilai ecopreneurship dengan pertimbangan karakteristik siswa SD sebagian besar berada dalam tahap operasional kongkret, artinya karakteristik anak SD dicirikan dengan pemikiran yang reversible, mulai mengkonfirmasi pemikiran tertentu, adaptasi gambaran yang menyeluruh, melihat suatu objek dari berbagai sudut pandang, mampu melakukan seriasi, dan berfikir kausalitas (Piaget, dalam Sadulloh dkk., 2006) sehingga dianggap sebagai cara akseleratif dalam menanamkan sikap peduli lingkungan sejak dini.

\section{METODE}

Penelitian ini menggunakan relevan dengan pengembangan pendekatan kualitatif melalui metode ecobrick di SD melalui kajian induktif. analisis deskriptif dengan objek Berikut tahapan penelitian ini dapat penelitian berupa data-data yang dilihat dalam gambar 1.0.

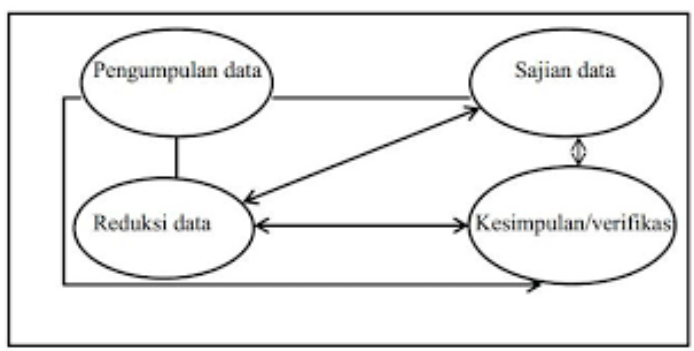

Gambar 1. Tahapan Penelitian Kualitatif (Zahara \& Aryanto, 2019

Prosedur penelitian meliputi sebagai upaya internalisasi nilai-nilai empat tahapan diantaranya : (1) ecopreneurship di SD. Kemudian pengumpulan data yang relevan dilakukan pendalaman kajian teorisesuai dengan variabel penelitian (2) teori yang relevan terkait konsep peneliti menyajikan data-data yang ecopreneurship sebagai framework telah terkumpul (3) reduksi dan inventarisasi data (4) menyimpulkan berdasarkan hasil verifikasi data yang valid dan reliabel (Cresswell, 2015)

Prosedur penelitian didahului hasil penelitian sebelumnya yang relevan dengan pengembangan ecobrick pengembangan program ecobrick di SD dan pengembangan ecobrick secara teoretis di SD. Hasil data tersebut dipilah kedalam tema- tema dan dilanjutkan untuk mendapatkan hasil yang mendalam melalui triangulasi data. 


\section{PEMBAHASAN}

A. Ecopreneurship

Framework

\section{Program Ecobrick}

Ecopreneurship dianggap sebagai solusi dalam mengatasi permasalahan lingkungan yang terjadi saat ini, khususnya dalam penanganan permasalah sampah di Indonesia. Pada hakikatnya konsep ecopreneurship menekankan kepada pemanfaat ekonomi yang berasal dari lingkungan alam. Oleh karena itu, orientasi ecopreneurship itu adalah lingkungan alam secara alamiah bukan regulasi pemerintah, pemangku kepentingan atau tekanan kelompok

tertentu (Schaper, 2002), sehingga secara definitif konsep ecopreneurship dicirikan sebagai aktivitas kewirausahaan berorientasi pada sistem manajemen atau prosedur teknis dan lebih berfokus pada inisiatif dan keterampilan pribadi orang atau tim wirausaha untuk mewujudkan kesuksesan pasar dengan inovasi lingkungan (Schaltegger, 2002). Pada mulanya konsep ecopreneurship hanya diterapkan dalam bidang ekonomi sesuai dengan grand theory Schaper (2002) dan Schaltegger (2002), namun setelah dianalisis melalui hasil penelitian yang dilakukan oleh Aryanto (2018) membuktikan bahwa konsep ini dapat diimplementasikan dalam dunia pendidikan di jenjang SD. Aryanto (2017) mengungkapkan bahwa secara konseptual ecopreneurship dibangun dari konsep ecolitercy dan enterpreneurship. Oleh karena itu, tujuan pengembangan konsep ecopreneurship di SD adalah untuk menjadikan peserta didik yang kreatif, inovatif dan semangat pantang menyerah seperti pengusaha yang diimbangi dengan perilaku ekologis, sehingga bisa menjaga, memanfaatkan, dan mengelola lingkungan alam dengan baik (Aryanto, 2017).

Salah satu gambaran perilaku ekologis (Green Behaviour) yang diharapkan dimiliki peserta didik SD menurut Supriatna (2016) dapat dilihat melalui Tabel 1.

\section{Tabel 1. Gambaran Perilaku ekologis}

\begin{tabular}{cll}
\hline No & Key Principles & \multicolumn{1}{c}{ Green Behaviour } \\
\hline 1 & $\begin{array}{l}\text { Respect for the } \\
\text { Earth }\end{array}$ & $\begin{array}{l}\text { Membuang sampah pada tempatnya } \\
\text { Memilah sampah organik dan anorganik } \\
\text { Menanam dan memelihara pohon di sekolah } \\
\text { Mematikan listrik pada ruang yang tidak dipakai } \\
\text { Memilih makanan organik } \\
\text { Memakai masker saat berpergian di jalan raya } \\
\text { Menegur teman yang melakukan tindakan tidak ramah } \\
\text { lingkungan }\end{array}$ \\
& Care for Life & $\begin{array}{l}\text { Menghindari produk makanan yang mengandung pengawet } \\
\text { Menghindari penggunaan kantung plastik }\end{array}$ \\
& $\begin{array}{l}\text { Adopt Patterns } \\
\text { of Production, } \\
\text { Consumption, } \\
\text { and } \\
\text { Reproduction }\end{array}$ & $\begin{array}{l}\text { Mengkonsumsi barang yang ramah lingkungan } \\
\text { Menggunakan satu botol plastik yang bisa disi ulang sebagai } \\
\text { tempat minum } \\
\text { Mendaur ulang sampah }\end{array}$
\end{tabular}


Hasil penelitian yang dilakukan oleh Aryanto (2018) yang mengusung "Pengembangan

Konsep Ecopreneurship di SDN 2 Cibabat Mandiri Kota Cimahi" memperjelas gambaran green behaviour yang dijelaskan oleh (Supriatna, 2016) sebagai bagian dari framework ecopreneurship secara konseptual dengan indikator SD tersebut sudah menerapkan program pemilahan dan pemanfaatan sampah menjadi barang yang usefull atau memiliki nilai jual sebagai alternatif penanaman nilainilai wirausaha sejak dini yang diinterpretasikan melalui program ecobrick.

B. Konsep Definitif Ecobrick kata ecology yang berarti dan brick yang berarti bata atau bisa disebut juga dengan bata ramah lingkungan. Ide ini dicetuskan oleh pasangan suami istri Russell Maier, pria asal Kanada dan Ani Himawati perempuan asal Indonesia yang memiliki rasa kepedulian sangat tinggi terhadap sejumlah negara berkembang, di Asia Tenggara khususnya dalam menghadapi permasalahan sampah plastik di Indonesia (Fathullah, 2018)

Ecobrick adalah salah satu cara penanganan limbah plastik dengan cara mengemas plastik yang bersih dan kering ke dalam botol plastik hingga kerapatan yang ditentukan. Saat ini produk ecobrick dibentuk menjadi sesuatu yang berguna seperti kursi, meja, dan lain-lain (Asih dan Fitriani, 2018).

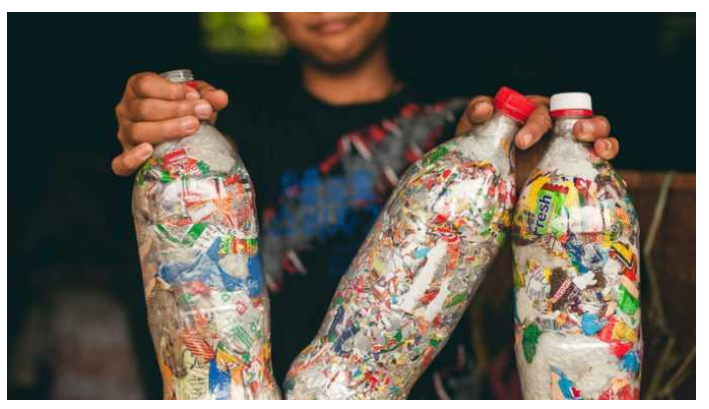

Gambar 2. Bentuk Ecobrick

\section{Implementasi Ecobrick di Sekolah Dasar}

Membuat ecobrick tidak sulit, dan sangat tepat diimplementasikan di SD. namun, ada beberapa pedoman ecobrick di SD diantaranya:

Produk tidak mengandung zat-zat yang akan menimbulkan korosi bagi plastik PET dari waktu ke waktu. (2) Produk dapat dibongkar/dipotong menjadi bagian-bagian yang dapat ditampung dalam leher dengan diameter $22 \mathrm{~mm}$ dari botol PET standar (kelas A ccobrick). (3) Produk tidak mengandung protusions/bentuk tajam yang bisa menusuk seorang yang mengerjakan ecobrick dari dalam saat sedang dikemas (misalnya kaca, logam). (4) Produk tidak mengandung bahan kimia reaktif, atau jika demikian, komponen ini jelas ditandai sebagai un-ecobrickable. (5) Produk tidak mengandung kertas, cairan atau bahan-bahan lain selain plastik. (6) Produk bisa masuk dalam leher/bidang dengan diameter atau ukuran 10-20 cm (ecobrick Kelas B). Hasil pembentukan ecobrick memberikan hasil yang dapat 
digunakan dalam kehidupan seharihari (Suminto, 2017:33)

Langkah-langkah yang dapat dilakukan dalam pembuatan ecobrick di SD adalah sebagai berikut: (1) Mengumpulkan botol-botol plastik bekas, seperti botol bekas kemasan minuman (misalnya air mineral), botol bekas kemasan minyak goreng dan lain sebagainya. Kemudian mencucinya hingga bersih, lalu dikeringkan; (2) mengumpulkan berbagai macam kemasan plastik, seperti kemasan mie instan, minuman-minuman instan, plastik pembungkus, tas plastik dan sebagainya. Harus dipastikan plastikplastik tersebut bebas dari segala jenis makanan (yang tersisa didalamnya), dalam keadaan kering dan tidak tercampur oleh bahan lain (klip, benang, kertas dan sebagainya); (3) memasukkan segala jenis plastik yang ada di poin ke 2 ke dalam botolbotol plastik pada poin ke 1; (4) tidak boleh tercampur dengan kertas, kaca, logam, benda-benda yang tajam dan bahan-bahan lain selain plastik. Bahan-bahan plastik yang dimasukkan ke dalam botol plastik harus dimampatkan hingga sangat padat dan mengisi seluruh ruangan dalam botol plastiknya; (5) cara memadatkannya bisa dengan menggunakan alat yang terbuat dari bambu atau kayu (seperti tongkat bambu atau kayu); (7) jika ingin membuat sesuatu dengan hasil ecobrick ini, misalnya membuat meja, kursi, atau bendabenda lain, maka bisa menggunakan botol-botol yang berukuran sama, atau bahkan dari jenis dan merk yang sama, sehingga memudahkan penyusunan; (8) jika menginginkan hasil yang berwarnawarni, maka plastik-plastik kemasan yang disusun didalamnya bisa diatur sedemikian rupa sehingga menghasilkan warna sesuai yang diinginkan. Bisa juga dengan cara membungkus botol plastik dengan cellophone/pita perekat yang berwarna; (9) Setelah semua botol plastik diisi dengan kemasankemasan plastik hingga padat, maka botol-botol plastik tersebut siap disusun dan digabungkan menjadi benda lain, seperti meja, kursi, bahkan dinding dan atau lantai panggung, pembatas ruangan dan banyak lagi lainnya; (10) untuk merekatkan satu botol dengan botol yang lainnya bisa menggunakan lem adesive atau bahan semen/gibs. Supaya bisa merekat kuat, botol-botol tersebut diikat kuat-kuat dengan menggunakan tali atau benang. Penggunaan tali rafia akan memberikan efek warna yang bagus sekaligus mengurangi sampah plastik dari jenis lain. (Suminto, 2017: 33-34).

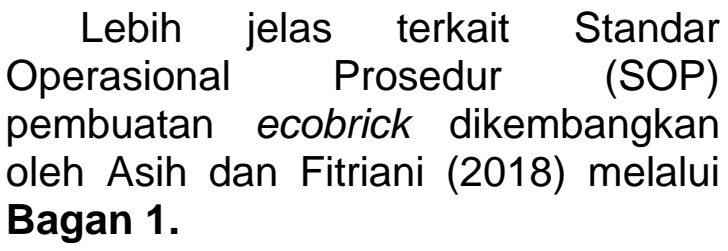




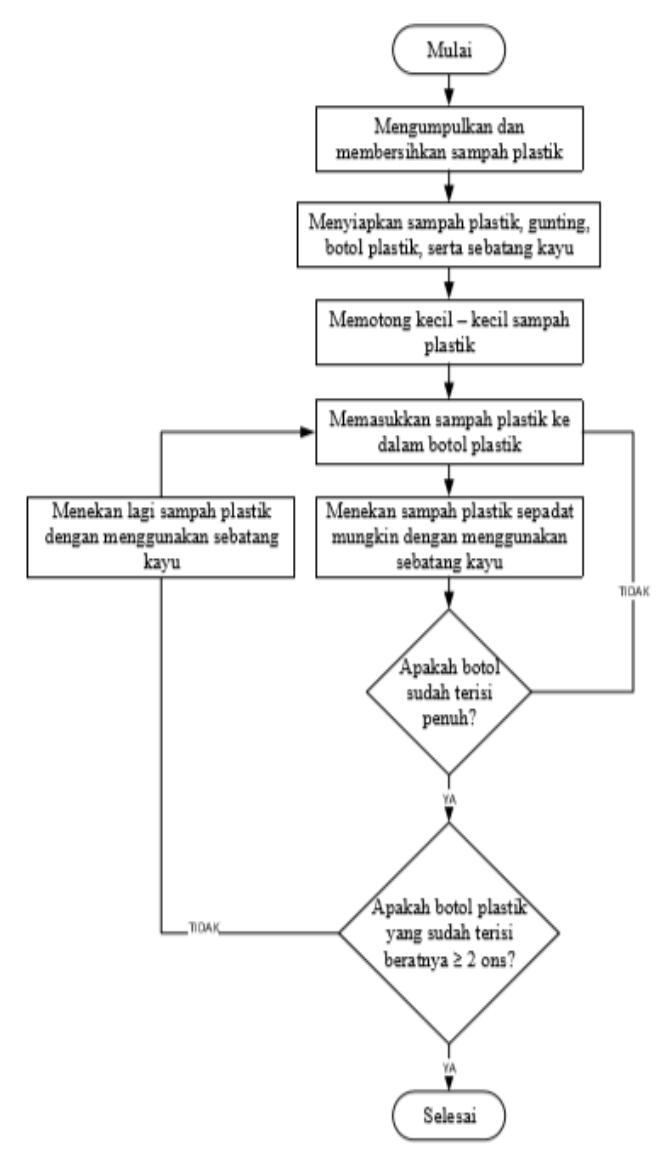

Gambar 3. SOP Pembuatan Ecobrick

Oleh karena itu, berdasarkan telah disusun Asih dan Fitriani (2018) gambar 3 maka proses pembuatan berdasarkan standarisasi hasil riset ecobrick yang tepat dilakukan di SD dan output produk yang jauh lebih adalah memperhatikan SOP yang baik.

\section{SIMPULAN}

Ecobrick dianggap sangat cocok diimplementasikan di SD karena secara teknis mudah diterapkan dengan bahan dan peralatan yang sangat mudah didapatkan karena memanfaatkan sampah sebagai unsur utama pembentukannya. Langkahlangkah pembuatan ecobrick sangat sederhana, dimulai dengan pengumpulan sampah ke dalam botol plastik sampai terisi penuh sehingga memiliki kerapatan dan kekuatan seperti layaknya batu bata. Langkah selanjutnya apabila ecobrick sudah banyak, maka dilanjutkan dengan proses pembentukan

ecobrick menjadi barang-barang yang memiliki nilai guna dan nilai jual, seperti: kursi, meja, bahan penunjang pembangunan pengganti batu bata, dan lain-lain yang dikemas secara kreatif. Oleh karena itu program ini dipandang

menginternalisasikan mampu ecopreneurship sejak dini sebagai langkah preventif dan kuratif terhadap permasalahan darurat sampah di Indonesia. Hasil penelitian diharapkan mampu menjadi alternatif bagi SD dalam mengembangkan program 
pengembangan diri yang kreatif dan inovatif sebagai upaya antisipatif dalam meminimalisir permasalahan lingkungan di Indonesia.

\section{DAFTAR PUSTAKA}

Aryanto, S. \& Syaodih, E. (2017). Development of Ecoprenuership in Primary School. International E-Journal of Advances in Education, Turkey 3 (99):597602

Aryanto, S. (2018). Pengembangan Ecopreneurship di Sekolah Dasar Inklusif. Bandung: Rumah Pena Pustaka

Aryanto, S. (2018). implementasi Ecopreneurship di Sekolah Dasar Inklusif. Bandung: Sekolah Pascasarjana Universitas Pendidikan Indonesia (Unpublished)

Asih, H.M. \& Fitriani, S. (2018). Penyusunan Standard Operating Procedure (SOP) Produksi Produk Inovasi Ecobrick. Jurnal IImiah Teknik Industri, Turkey 17 (2):144-150

Creswell, J. (2015). Riset pendidikan perencanaan, pelaksanaan, dan evaluasi riset kualitatif dan kuantitatif (edisi kelima). Yogyakarta: Pustaka Pelajar

Fathullah, A.A. (2019). Ecobrick Solusi Sederhana Selamatkan Dunia. Diakses tanggal 19 Agustus 2019 pukul 15.03 dari: https://www.kompasiana.com/ag usfathullah/5b484862dd0fa852cc 530dd2/ecobrick-solusisederhana-namun-efektif

Indopos (2019). Sampah Menjadi Masalah Lingkungan di Indonesia. Diakses tanggal 19 Agustus 2019 pukul 15.07 dari: https://indopos.co.id/read/2018/0 6/26/142392/kota-bekasidarurat-lahan-tpa-sampah/
Kurnia, N. (2019). Sampah Menjadi Masalah Lingkungan di Indonesia. Diakses tanggal 19 Agustus 2019 pukul 15.03 dari: https://www.kompasiana.com/nin ingkurnia/5cbef26595760e2b081 e54a4/sampah-menjadimasalah-lingkungan-diindonesia?page =all

Oktapianto. (2016). Peningkatan Ekoliterasi Siswa dalam Pemanfaatan Sampah Kertas dengan Model Project Based Learning pada Pembelajaran IPS. Bandung: Sekolah Pascasarjana Universitas Pendidikan Indonesia (Unpublished)

Sadulloh, U. (2009). Filsafat pendidikan. Bandung: Alfabeta

Schaltegger, S. (2002). A Framework forEcopreneurship. Greener Management International. 20(38): 45-58

Schaper, M. (2002). The Essence of Ecopreneurship.Greener Management International. 20(38): $26-30$

Suminto, S. (2017). Ecobrick Solusi Cerdas dan Kreatif untuk Mengatasi Sampah Pelastik. Productum: Jurnal Desain Produk (Pengetahuan dan Perancangan Produk) 3 (1):2634

Supriatna, N. 2016. Local Wisdom in Constructing Students Ecoliteracy Through Ethnopedagogy and Ecopedagogy . Bandung: Atlantis Press.

Wahyuni, T. (2016). Indonesia Penyumbang Sampah Terbesar 
Kedua di Dunia. Diakses tanggal 19 Agustus 2019 pukul 14.57 dari:

http://www.cnnindonesia.com/ga ya-hidup/20160222182308-277112685/indonesia-penyumbangsampah-plastik-terbesar-ke-duadunial
Zahara, T. Rony \& Aryanto, S. 2019. Coching Competence as A Solution For Headmaster in Disruption Era. International Conference on Bussines Law and Pedagogy . Vol. 1, No $1 \mathrm{pp}$ $1-10$ 